\title{
NAZMI BOSNA: HIS LIFE, WORKS AND CONTRIBUTIONS TO CLASSICAL GUITAR EDUCATION $^{1}$
}

\author{
Nazmi Bosna: Hayatı, Eserleri ve Gitar Eğitimine Katkıları
}

Kaan ÖZTUTGAN *

\begin{abstract}
The aim of this study is to give information about the life and works of Nazmi Bosna, and to reveal his contributions to guitar education. In this descriptive study, data were collected through literature review, interview and document review. The works of Nazmi Bosna were identified and these works were analyzed via document analysis within the scope of the study. Bosna's works were tabulated according to the name of the work, time signature, tonality and, if any, the person or people to whom the work is dedicated. The results displayed that Bosna began his guitar education by studying classical guitar with Ziya Aydıntan, and continued his academic classical guitar education as a student of Miguel Rubio in Bern Conservatory in Switzerland. Also, he made his first composition in 1963, and has continued to compose since then. Similarly, Bosna wrote 9 books, and 8 of them included 230 compositions of different tonality and genre. He also has a book, Guitar Applied Harmony Teaching. He contributed to guitar education with his own works and with the students he trained. Last but not the least, it was found that Bosna was a composer who had the most original works published for solo classical guitar in Turkey.
\end{abstract}

Keywords: Music, Classical Guitar, Classical Guitar Education, Nazmi Bosna, Descriptive Study.

\section{ÖZ}

Bu araştırmanın amacı Nazmi Bosna'nın hayatı ve eserleri hakkında bilgi vermek, gitar eğitimine katkılarını ortaya koymaktır. Betimsel bir araştırma olan bu makalede veriler; kaynak taraması, görüşme ve doküman incelemesi yoluyla toplanmıştır. Araştırma kapsamında Nazmi Bosna'nın eserleri belirlenmiş ve bu eserler doküman incelemesi yoluyla analiz edilmiştir. Bosna'nın eserleri; eser adına, ölçü birimine, tonalitesine ve varsa ithaf edilen kişi ya da kişilere göre tablolaştırılmıştır. Bu tablolar yorumlanarak, incelenen eserler hakkında genel bilgiler verilmiş ve bestecinin gitar eğitimine katkıları ortaya konulmuştur. Çalışmada; Bosna'nın Ziya Aydıntan'dan klasik gitar dersleri alarak gitar öğrenimine başladığı, akademik anlamda klasik gitar eğitimine İsviçre'nin Bern Konservatuvarında Miguel Rubio'nun öğrencisi olarak devam ettiği, ilk bestesini 1963 yllında yaptığ ve bu tarihten günümüze kadar beste yapmaya devam ettiği, yayınlanmış 9 kitabı olduğu, bu kitapların 8 'inde farklı tonalite ve türde 230 bestesinin bulunduğu, bir adet Gitar Uygulamalı Armoni Öğretimi kitabı bulunduğu, eserleri ve yetiştirdiği öğrencilerle gitar eğitimine katkı sağladığı, ülkemizde solo klasik gitar için yayınlanmış en fazla özgün eseri bulunan bestecinin Nazmi Bosna olduğu sonuçlarına ulaşılmıştır.

Anahtar Kelimeler: Müzik, Klasik Gitar, Klasik Gitar Eğitimi, Nazmi Bosna, Betimsel Araştırma.

\footnotetext{
${ }^{1}$ Derleme Makalesi/Review Article Geliş Tarihi/Received Date: 17.04.2021 Kabul Tarihi/Accepted Date: 17.05.2021

* Sorumlu Yazar/Corresponding Author: Dr. Öğr. Üyesi, Osmaniye Korkut Ata Üniversitesi, Mimarlık Tasarım ve Güzel Sanatlar Fakültesi, Müzik Bölümü, Müzik Anasanat Dalı, kaanozt@ hotmail.com ORCID: 0000-0002-3489-5709
} 
Composing requires extensive knowledge of many subjects such as harmony, form, style and composition techniques besides certain skills. In addition to all this, knowing the instrument or instruments that are used for composition is one of the basic elements of creating a strong work in terms of technique and expression. That's why, throughout history, many composers have preferred to compose considering the opinions of the performers who mastered the instrument they wrote for, or compositions were made directly by the performers. This situation is similar to the historical development of the classical guitar repertoire. It is possible to say that the performers composing for the guitar as well as the non-guitarist composers played an important role in the development of the guitar both in terms of repertoire, technical and pedagogical aspects.

Performers of classical guitar or guitar-like instruments have written works for guitar based on their own experiences, with or without a composition training (Ranjbari, 2013, p.6). Considering the classical guitar repertoire dating back to the $16^{\text {th }}$ century, it can be said that the original compositions for the guitar were carried out by guitarist composers for a long time. Many important guitarists such as Alonso Mudarra, Luis de Narvaez, Robert de Visee, Gaspar Sanz, Fernando Sor, Mauro Giuliani, Matteo Carcassi, Ferdinando Carulli, Dionisio Aguado, Francesco Molino, Giulio Regondi, Napoleon Coste, Kaspar Mertz, Francisco Tarrega, Miguel Llobet, Agustin Barrios made original compositions for guitar during this period (Jeffery, 2002, p.108-110). The classical guitar repertoire, which developed mostly with the works of guitarist composers until 1920, has been enriched with the contributions of non-guitarist composers since then (Ünlenen, 2016, p.112). This period, in which some guitarist composers have adapted works written for other instruments into classical guitar, forms the basis of classical guitar education and repertoire.

With the initiatives of the famous Spanish Guitarist Andres Segovia, non-guitarist composers also started composing for classical guitar and contributed to the repertoire with works composed mainly in sonata and concerto forms or pedagogical works (Ünlenen, 2016, p.112) in 1920. Some of these non-guitarist composers are Manuel Maria Ponce, Federico Morena Torroba, Joaquin Turina, Mario Castelnuovo-Tedesco, Joaquin Rodrigo, William Walton, Lennox Berkeley, Stephen Dodgson and Benjamin Britten (Jeffery, 2002, p.110). The works of these pioneer composers attracted attention all over the world, and contributed to the non-guitarist composers in different places to compose for classical guitar. Today, new works are composed in various forms by composers who are guitarists or non-guitarists around the world, and the classical guitar repertoire continues to enrich.

As well as all over the world, many guitarists such as Bekir Küçükay, Safa Yeprem, Cem Küçümen, Nazmi Bosna and many non-guitarists such as Yalçın Tura, Ertuğ Korkmaz, Turgay Erdener, Nejat Başeğmezler, who compose for classical guitar in our country, have contributed to the guitar repertoire with their original works (Yeprem, 2013, p.17-30). Among them, Nazmi Bosna draws attention with the great increase in the number of solo guitar compositions he has made in the last decade. To this end, the aim of this research is to give information about the life and works of Nazmi Bosna, and to reveal his contributions to guitar education. 


\section{Method}

This study is a descriptive study based on the data collected through literature review, interviews and document review, which aims to reveal the life and works of Nazmi Bosna, and his contributions to guitar education. Within the scope of the research, primarily a literature review was done, and in-depth interviews were conducted with Nazmi Bosna both in person and via telephone. These interviews were audio-recorded, and transcribed for use throughout the research. Afterwards, the works of Nazmi Bosna were determined in line with the data collected through literature review and interviews, and these works were analyzed through document analysis.

Nazmi Bosna's works were tabulated according to the name of the work, time signature, tonality and, if any, the person or people dedicated to. A general information was given about his works and the contributions of the composer to the guitar education were revealed by interpreting these tables. The composer's opinion was also taken at the stage of determining the tonalities. Also, the works that could not be evaluated within a single tonality or ended by changing to a different tone from the starting tone are shown in the table with "*". The results of the research were interpreted in accordance with literature review, document analysis and interviews.

\section{Findings}

\section{Life of Nazmi Bosna}

Nazmi Bosna was born in 1946 in Kırıkkale (Nazmi Bosna,2021). The childhood of Nazmi Bosna, the youngest of three children of a Yugoslav immigrant family, passed in Kırıkkale. He completed his primary, secondary and high school education there. The first melodies he heard were the Balkan folk songs his father sang. Impressed by his father's interest in music, he began learning harmonica and mandolin during his secondary school years. In the same years, he started to do musical works by meeting on weekends with his friends who were interested in music and could play a musical instrument (Nazmi Bosna, Personal Interview 2019, April 22, Ankara).

After completing his high school education, he went to Ankara Academy of Economic and Commercial Sciences, and settled in Ankara in 1963. As a result of his quest to continue his music-related studies in Ankara, he met Ziya Aydıntan, one of the few classical guitar instructors in those years. Nazmi Bosna, who participated in Aydıntan's classical guitar lessons and choral works, was influenced by classical guitar music and directed his works towards guitar. During these years, he gave successful concerts by participating in the choir, guitar orchestra and student concerts prepared by Ziya Aydıntan for his students. Thanks to the mandolin, baglama and music theory lessons he had previously taken, he made rapid progress in his guitar studies. After a while, Nazmi Bosna began to perform solo works in concerts and to compose for guitar, and became one of Aydintan's best students.

After graduating from Ankara Academy of Economic and Commercial Sciences, he did his military service as a reserve officer between 1968-1970, and later began to work at the Ministry of Industry. Continuing his classical guitar studies in this process, Bosna decided to study classical guitar (Nazmi Bosna, Personal Interview 2019, April 22, Ankara). Upto that point, there was not any other institution providing education at undergraduate level in Turkey for classical guitar education at the level of bachelor's degree was given for the first time in 1977 at the State Conservatory of Mimar Sinan University (Elmas, 2003, p.55). For this reason, he had contacted with his relatives living in Switzerland to study abroad. With the support of his relatives and the letter of invitation they sent, Bosna obtained the right to reside and study in Switzerland. Thus, he resigned from his position in the 
Ministry of Industry, where he had worked for about a year, and went to Switzerland (Nazmi Bosna, Personal Interview 2019, April 22, Ankara).

Nazmi Bosna, who settled in Switzerland in 1971, continued his guitar studies on his own while attending language courses in order to learn German well. After learning German at an educational level, he applied to the Classical Guitar Department of Bern Conservatory. Bosna, who was found successful by the jury in the talent exam, became a student of the famous guitarist and guitar instructor Miguel Rubio in the Classical Guitar Department of the Bern Conservatory in 1971. He continued to compose for classical guitar during this period, during which he improved his music theory and guitar knowledge. Upon the request of Miguel Rubio, he sang the piece he composed, named "Praeludium" at the end of the year exam held as a public concert (Nazmi Bosna, Personal Interview 2019, April 22, Ankara). His composition won the admiration of many, especially Miguel Rubio and his classmates. During his education in Switzerland, he taught classical guitar at Musikschule der Region Burgdorf, Musikschule Muri-Gümligen and Musikschule Mooessedorf (Nazmi Bosna, 2021).

Bosna returned to Turkey in 1974 and started working in the Ministry of Tourism. Until 1980, he both continued his civil service and gave guitar lessons in Ankara. During this period, he gave guitar lessons to many students, including Ahmet Kanneci. During his stay abroad, he served as the Culture and Promotion Attaché at our Embassies and Consulates General. His piece Andante Religiosa, which he composed for guitar, was arranged for the orchestra while he was working in Berlin between 2004-2008, and was performed for the first time in Berlin by the orchestra of Jounggenc (Nazmi Bosna, Personal Interview 2021, February 19, Ankara).

During his 34-year tenure at the Ministry of Tourism, he did not break his ties with music and guitar. He continued to compose for classical guitar by buying many guitar notes, guitar albums and music books, increasing his musical knowledge in this period. He participated in many concerts as a listener, although he was unable to perform guitar studies and concerts due to his workload in his civil service (Nazmi Bosna, Personal Interview 2021, March 14, Ankara).

Bosna, who has published his compositions into books, has 9 published books: 42 Pieces for Classical Guitar ( $1^{\text {st }}$ book), 20 Pieces for Classical Guitar ( $2^{\text {nd }}$ Book), 30 Pieces for Classical guitar “Anatolian Breezes” ( $3^{\text {rd }}$ book), 25 Pieces for Classical Guitar ( $4^{\text {th }}$ Book), 27 Pieces for Classical Guitar ( $5^{\text {th }}$ Book $), 23$ Pieces for Classical Guitar “Anatolian Breezes" (6 $6^{\text {th }}$ Book), 34 Pieces for Classical Guitar ( $7^{\text {th }}$ Book), 19 Pieces for Classical Guitar "Anatolian Breezes" ( $8^{\text {th }}$ Book), and Guitar Applied Harmony Teaching ( $9^{\text {th }}$ Book). Still continuing to compose for classical guitar, Bosna continues to work to publish new books.

\section{Works of Nazmi Bosna}

In this section, the works prepared and published in a book by Nazmi Bosna are listed starting from the oldest year of publication, and examined giving tag information.

42 pieces for classical guitar (1. book). There are 42 original works composed for classical guitar by Nazmi Bosna in this 137-page book published by Bemol Music Publishing in September 2011. These works dates back to 1963 until the publication date of the book. (Bosna, 2011a). The works in the book are presented in Table 1. 
Table 1. Pieces in the $1^{\text {st }}$ Book

\begin{tabular}{|c|c|c|c|}
\hline Name of Work & Dedicated to & Tonality & Time Signature \\
\hline Etude No.1 & - & A Minor & $2 / 4$ \\
\hline Etude No.3 & - & E Minor & $7 / 8-4 / 4$ \\
\hline Etude No.7 & - & E Minor & $3 / 4-4 / 4-2 / 4$ \\
\hline Etude No.8 & M.Safa Yeprem & D Minor & $4 / 4-2 / 4-3 / 4-3 / 8-5 / 8-6 / 8$ \\
\hline Etude No.9 & 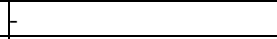 & E Minor & $3 / 4-5 / 4-4 / 4-2 / 4$ \\
\hline Etude No.10 & f & E Minor & $2 / 4$ \\
\hline Etude No.11 & - & A Minor & $2 / 4$ \\
\hline Etude No.12 & - & $*$ & $2 / 4-3 / 4$ \\
\hline Etude No.13 & - & C Major & $2 / 4-3 / 4$ \\
\hline Etude No.14 & - & A Major & $2 / 4-3 / 4$ \\
\hline Etude No.16 & - & G Major & $2 / 4$ \\
\hline Etude No.17 & f & $*$ & $2 / 4-3 / 4$ \\
\hline Etude No.21 & f & D Minor & $2 / 4$ \\
\hline Nocturne No.1 & f & E Minor & $3 / 4-2 / 4-4 / 4$ \\
\hline Nocturne No.3 & f & E Minor & $3 / 4-2 / 4$ \\
\hline Prelude No.1 & - & D Minor & $2 / 4-3 / 4$ \\
\hline Prelude No.2 & Miguel Rubio & E Minor & $3 / 8-4 / 4-3 / 4-2 / 4$ \\
\hline Prelude No.3 & - & G Minor & $2 / 4-3 / 4$ \\
\hline Tanz No.1 & - & A Major & $2 / 4-6 / 8-9 / 8-7 / 8-5 / 8-3 / 4-3 / 8-8 / 8$ \\
\hline Tanz No.2 & 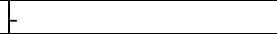 & A Minor & $3 / 4-6 / 8-8 / 8-5 / 8-3 / 8$ \\
\hline Tanz Der Inka & - & E Minor & $8 / 8$ \\
\hline Walzer No.4 & - & E Minor & $(3 / 4-6 / 8)$ \\
\hline Walzer No.5 & 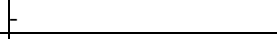 & E Minor & $6 / 8$ \\
\hline Walzer No.6 & Bekir Küçükay & A Minor & $(3 / 4-6 / 8)$ \\
\hline Walzer No.7 & - & E Minor & $(6 / 8-3 / 4)$ \\
\hline Walzer No.8 & - & E Minor & $(6 / 8-3 / 4)$ \\
\hline Walzer No.9 & 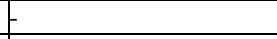 & D Minor & $3 / 4$ \\
\hline \begin{tabular}{|l|} 
Tango No.1 \\
\end{tabular} & - & G Minor & $4 / 4$ \\
\hline Tango No.2 & - & A Minor & $4 / 4$ \\
\hline Tango No.3 & - & C Minor & $4 / 4-8 / 8$ \\
\hline Milonga No.1 & - & A Minor & $2 / 4$ \\
\hline Milonga No.2 & - & D Minor & $2 / 4$ \\
\hline Milonga No.4 & - & A Minor & $2 / 4$ \\
\hline Milonga No.5 & - & D Minor & $2 / 4$ \\
\hline Milonga No.6 & - & A Minor & $2 / 4$ \\
\hline Barcelona-Erinnerungen & 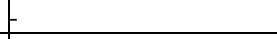 & E Major & $3 / 4-2 / 4$ \\
\hline Ein Abend In Madrid & - & E Minor & $3 / 4-2 / 4$ \\
\hline Elegie & - & E Minor & $3 / 4-12 / 8-4 / 4-2 / 4$ \\
\hline Grand Solo & 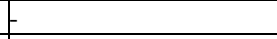 & $*$ & $2 / 4-3 / 4-4 / 4$ \\
\hline Menuett & - & E Major & $3 / 4$ \\
\hline Traum & - & C Major & $4 / 4-3 / 4-2 / 4-3 / 8$ \\
\hline Romanze No.1 & Tülin-Güner Sarısözen & A Major & $3 / 4-2 / 4-4 / 4$ \\
\hline
\end{tabular}

When Table 1 is examined, it is seen that the composer included works in different types of western music in this book. The approximate percentage for these works is 30.9\% Etude, 14.2\% Walzer, 11.9\% Milonga, 7.1\% Tango, 7.1\% Prelude, 4.7\% Nocturne. 4.7\% Tanz, 2.3\% Tanz Der Inka, 2.3\% Elegie, 2.3\% Grand Solo, 2.3\% Menuett, 2.3\% Romanze has 2.3\% Barcelona-Erinnerungen, 2.3\% Ein Abend In Madrid, 2.3\% Traum. In addition, it is possible to say that time signature has been changed in approximately $52 \%$ of the works in the book.

When evaluated in terms of tonality, approximately $33 \%$ of the works are in E Minor, $19 \%$ in A Minor, $14 \%$ in D Minor, 7\% in A Major, 5\% in C Major, 5\% in G Minor, 5\% in E Major, 2\% in G Major, 2\% in C Minor. On the other hand, $7 \%$ are in the category of works which can not be evaluated in a single tonality or are terminated by transition from the starting tone to a different tone. The book also contains a work dedicated to M. Safa Yeprem, Miguel Rubio, Bekir Küçükay and Tülin-Güner Sarısözen.

20 pieces for classical guitar (2. book). In this 78-page book published by Bemol Music Publishing in September 2011, there are 20 original works composed for classical guitar by Nazmi Bosna. These works date back to 1963 until the publication date of the book. (Bosna, 2011b). The works in the book are presented in Table 2. 
Table 2. Pieces in the $2^{\text {nd }}$ Book

\begin{tabular}{|l|l|l|l|}
\hline Name of Work & Dedicated to & Tonality & Time Signature \\
\hline Etude No.2 & Ahmet Kanneci & E Minor & $3 / 4-10 / 16-3 / 8-2 / 4-5 / 8-9 / 16-13 / 16-7 / 16-5 / 16$ \\
\hline Etude No.4 & Ahmet Kanneci & A Minor & $2 / 4-3 / 8-10 / 16-7 / 16-4 / 4-3 / 4-12 / 16-5 / 16-5 / 8$ \\
\hline Etude No.5 & Ahmet Kanneci & A Minor & $3 / 4-6 / 8-7 / 8-5 / 8-2 / 4-9 / 8-12 / 8-3 / 8$ \\
\hline Etude No.6 & Ahmet Kanneci & A Major & $2 / 4-3 / 4$ \\
\hline Etude No.15 & Ahmet Kanneci & $*$ & $3 / 4-2 / 4$ \\
\hline Etude No.18 & Ahmet Kanneci & $*$ & $2 / 4-3 / 4$ \\
\hline Etude No.19 & Ahmet Kanneci & D Minor & $2 / 4-3 / 4-6 / 8-9 / 8$ \\
\hline Etude No.20 & Ahmet Kanneci & A Minor & $3 / 4-2 / 4$ \\
\hline Serenade No.1 & Ahmet Kanneci & $*$ & $2 / 4-3 / 4-5 / 4-4 / 4$ \\
\hline Serenade No.2 & Ahmet Kanneci & E Major & $3 / 4-6 / 8-4 / 4-2 / 4-3 / 8$ \\
\hline Serenade No.3 & Ahmet Kanneci & E Minor & $3 / 8$ \\
\hline Nocturne No.2 & Ahmet Kanneci & E Minor & $3 / 4-2 / 4-4 / 4$ \\
\hline Walzer No.1 & Ahmet Kanneci & A Minor & $(3 / 4-6 / 8)$ \\
\hline Walzer No.2 & Ahmet Kanneci & A Minor & $(3 / 4-6 / 8)$ \\
\hline Walzer No.3 & Ahmet Kanneci & E Minor & $3 / 4$ \\
\hline Tango No.4 & Ahmet Kanneci & G Minor & $4 / 4$ \\
\hline Milonga No.3 & Ahmet Kanneci & $*$ & $2 / 4$ \\
\hline Andante Religioso & Ahmet Kanneci & D Minor & $2 / 4-3 / 4$ \\
\hline Spanische Caprichio & Ahmet Kanneci & D Minor & $2 / 4-3 / 4-4 / 4-3 / 8-5 / 4-5 / 8$ \\
\hline Romanze No.2 & Ahmet Kanneci & G Minor & $6 / 8-3 / 8$ \\
\hline
\end{tabular}

Table 2 indicated that the composer includes works in different types of western music in this book. $40 \%$ of works have Etude, 15\% Walzer, 15\% Serenade, 5\% Milonga, 5\% Tango, 5\% Nocturne, 5\% Romanze, 5\% Andante Religioso and $5 \%$ Spanische Caprichio titles. Also, it is possible to say that time signature has been changed in approximately $56 \%$ of the works in the book.

As for tonality, approximately $25 \%$ of the works have A Minor, 20\% E Minor, 15\% D Minor 10\% G Minor, $5 \%$ A Major, $5 \%$ E Major while $20 \%$ of works can not be evaluated within a single tonality or are terminated changing to a different tone from the initial tone. All of the works in the book are dedicated to Ahmet Kanneci.

30 pieces for classical guitar "Anatolian Breezes" (3. book). In this 100-page book published by Sage Publishing in November 2014, there are 30 original works composed for classical guitar by Nazmi Bosna. Except for No.2, No.5 and No.7, all other works were conducted after 2011 (Bosna, 2014a). The works and information about them are presented in Table 3.

Table 3. Pieces in the $3^{\text {rd }}$ Book

\begin{tabular}{|c|c|c|c|}
\hline Name of Work & Dedicated to & Tonality & Time Signature \\
\hline Anatolian Breeze No.1 & - & D Minor & $5 / 8-3 / 8$ \\
\hline Anatolian Breeze No.2 & - & D Minor & $3 / 4-2 / 4$ \\
\hline Anatolian Breeze No.3 & - & C Minor & $3 / 8-5 / 8-6 / 8$ \\
\hline Anatolian Breeze No.4 & - & A Minor & $9 / 8-5 / 8-6 / 8-7 / 8$ \\
\hline Anatolian Breeze No.5 & - & D Major & $3 / 4-4 / 4-6 / 8$ \\
\hline Anatolian Breeze No.6 & - & $*$ & $7 / 8-3 / 4-3 / 8-4 / 4-2 / 4-5 / 8-6 / 8$ \\
\hline Anatolian Breeze No.7 & - & $*$ & $5 / 8-3 / 8-4 / 4-2 / 4-3 / 4$ \\
\hline Anatolian Breeze No.8 & - & $*$ & $8 / 8-5 / 8-9 / 8-7 / 8-2 / 4-6 / 8$ \\
\hline Anatolian Breeze No.9 & - & $*$ & $3 / 8$ \\
\hline Anatolian Breeze No.10 & - & $*$ & $8 / 8-5 / 8-9 / 8-3 / 4-7 / 8-10 / 8-6 / 8-2 / 4$ \\
\hline Anatolian Breeze No.11 & - & D Minor & $7 / 8-8 / 8-2 / 4-5 / 8-6 / 8-3 / 8-4 / 4-3 / 4$ \\
\hline Anatolian Breeze No.12 & - & A Minor & $5 / 8-2 / 4-3 / 4-3 / 8-6 / 8$ \\
\hline Anatolian Breeze No.13 & - & $*$ & $7 / 8-9 / 8-3 / 4-5 / 8-3 / 8-2 / 4$ \\
\hline Anatolian Breeze No.14 & - & A Minor & $3 / 4-2 / 4-7 / 8-6 / 8-3 / 8$ \\
\hline Anatolian Breeze No.15 & - & A Minor & $3 / 8-5 / 8-3 / 4-2 / 4-4 / 4-7 / 8-9 / 8-10 / 8-12 / 8-6 / 8$ \\
\hline Anatolian Breeze No.16 & - & A Minor & $3 / 4-2 / 4-4 / 4-5 / 4$ \\
\hline Anatolian Breeze No.17 & - & D Major & $6 / 8-3 / 4-7 / 8-5 / 8-9 / 8$ \\
\hline Anatolian Breeze No.18 & - & D Minor & $9 / 8-7 / 8-5 / 8-6 / 8-3 / 4-2 / 4-3 / 8$ \\
\hline Anatolian Breeze No.19 & - & A Minor & $4 / 4-2 / 4-3 / 4-8 / 8-5 / 8-6 / 8-9 / 8-7 / 8-3 / 8$ \\
\hline Anatolian Breeze No.20 & - & G Minor & $5 / 8-7 / 8-9 / 8-3 / 8-3 / 4-2 / 4-8 / 8$ \\
\hline Anatolian Breeze No.21 & - & C Minor & 9/8-7/8-10/8-8/8-5/8-3/8-2/4-6/8-4/4-3/4 \\
\hline Anatolian Breeze No.22 & - & D Minor & $7 / 8-5 / 8-3 / 8-9 / 8-6 / 8-2 / 4-3 / 4$ \\
\hline Anatolian Breeze No.23 & - & D Minor & $9 / 8-7 / 8-2 / 4-4 / 4-3 / 4-3 / 8$ \\
\hline
\end{tabular}




\begin{tabular}{|l|l|l|l|}
\hline Anatolian Breeze No.24 & - & A Minor & $7 / 8-5 / 8-2 / 4-6 / 8-3 / 4-9 / 8-8 / 8$ \\
\hline Anatolian Breeze No.25 & - & $*$ & $5 / 8-3 / 4-2 / 4-7 / 8-9 / 8-3 / 8-6 / 8-4 / 4$ \\
\hline Anatolian Breeze No.26 & - & C Minor & $5 / 8-7 / 8-3 / 8-3 / 4-2 / 4-9 / 8$ \\
\hline Anatolian Breeze No.27 & - & $*$ & $9 / 8-5 / 8-3 / 8-3 / 4-2 / 4-8 / 8$ \\
\hline Anatolian Breeze No.28 & Turkish People & F Minor & $3 / 4-4 / 4-5 / 4-3 / 8-2 / 4-7 / 8-5 / 8-6 / 8-9 / 8-8 / 8$ \\
\hline Anatolian Breeze No.29 & İsmail Sezen & $*$ & $3 / 8-5 / 8-2 / 4-7 / 8-8 / 8-3 / 4$ \\
\hline Anatolian Breeze No.30 & Our Martyrs & $*$ & $2 / 4-4 / 4-3 / 4$ \\
\hline
\end{tabular}

It is seen in Table 3 that the composer preferred a general name "Anatolian Breeze" for the works in this book. That's why, it is not possible to make a definite judgment about the type of works and to make a classification. However, it is possible to say that the time signature has been changed in approximately $96 \%$ of the works in the book.

When evaluated in terms of tonality, approximately $23 \%$ of the works have A Minor, 20\% D Minor, $10 \% \mathrm{C}$ Minor, 7\% D Major, 3\% G Minor, and 3\% F Minor while 33\% of works can not be evaluated within a single tonality or are terminated changing to a different tone from the initial tone. The book contains works dedicated to the Turkish people, İsmail Sezen and Our Martyrs.

25 pieces for classical guitar (4. book). In this 87-page book published by Sage Publishing in November 2014, there are 25 original works of Nazmi Bosna composed for classical guitar. Except for Piece No. 2, Piece No. 3, Piece No. 4, Piece No. 5, Piece No. 6, Piece No. 7, Piece No. 8, Piece No. 9, Piece No. 10 and Piece No. 21, the other works were done after 2011 (Bosna, 2014b). The works and information about them are given in Table 4.

Table 4. Pieces in the $4^{\text {th }}$ Book

\begin{tabular}{|l|l|l|l|}
\hline Name of Work & Dedicated to & Tonality & Time Signature \\
\hline Nocturne No.4 & Fazıl Say & E Minor & $2 / 4-3 / 4-3 / 8$ \\
\hline Etude No.22 & Fazıl Say & G Minor & $12 / 8$ \\
\hline Walzer No.10 & Süleyman Tarman & A Minor & $3 / 4$ \\
\hline Piece No.1 & - & A Minor & $9 / 8-6 / 8$ \\
\hline Piece No.2 & - & C Minor & $2 / 4$ \\
\hline Piece No.3 & - & E Minor & $6 / 8-3 / 4$ \\
\hline Piece No.4 & - & D Minor & $3 / 4$ \\
\hline Piece No.5 & - & D Major & $2 / 4-3 / 4$ \\
\hline Piece No.6 & - & D Minor & $3 / 4-2 / 4-4 / 4$ \\
\hline Piece No.7 & - & D Minor & $3 / 4$ \\
\hline Piece No.8 & A Minor & $4 / 4$ \\
\hline Piece No.9 & A Minor & $3 / 4-2 / 4-4 / 4$ \\
\hline Piece No.10 & A Minor & $3 / 8-3 / 4-5 / 8-6 / 8-2 / 4-7 / 8$ \\
\hline Piece No.11 & Bujor Hoinic & E Minor & $3 / 8$ \\
\hline Piece No.12 & Bujor Hoinic & F Minor & $3 / 4$ \\
\hline Piece No.13 & Ercüment Burak Erdoğan & E Minor & $3 / 4-2 / 4-4 / 4$ \\
\hline Piece No.14 & İsmail Sezen & $*$ & $3 / 4$ \\
\hline Piece No.15 & Ismail Sezen & E Minor & $3 / 8$ \\
\hline Piece No.16 & Ercüment Burak Erdoğan & $*$ & $3 / 4-2 / 4$ \\
\hline Piece No.17 & Bujor Hoinic & E Minor & $2 / 4-3 / 4$ \\
\hline Piece No.18 & - & A Major & $2 / 4$ \\
\hline Piece No.19 & İsmail Sezen & E Major & $3 / 4$ \\
\hline Piece No.20 & Bujor Hoinic & D Minor & $4 / 4-2 / 4-3 / 4$ \\
\hline Piece No.21 & & $4 / 4$ \\
\hline Tango No.5 & & & $3 / 4-2 / 4-4 / 4$ \\
\hline
\end{tabular}

Table 4 shows that the composer includes works in different types of western music in this book. Of these works, $84 \%$ have the title Piece, $4 \%$ Walzer, $4 \%$ Tango, $4 \%$ Nocturne and $4 \%$ Etude. The composer preferred a general name "Piece" in most of the works in this book. For this reason, it is not possible to make a definite judgment and classification about the type of works with the title of "Piece". Yet, it is possible to say that the time signature has been changed in $52 \%$ of the works in the book. 
While approximately $28 \%$ of the works are in E Minor, $20 \%$ in A Minor, $16 \%$ in D Minor, $8 \%$ in A Major, $4 \%$ in G Minor, 4\% in D Major, 4\% F Minor and 4\% C Minor, 12\% of the works can not be evaluated in a single tonality or are terminated changing to a different tone from the initial tone. The book includes works dedicated to Fazıl Say, Süleyman Tarman, Bujor Hoinic, Ercüment Burak Erdoğan and İsmail Sezen.

27 pieces for classical guitar (5. book). In this 108-page book published by Sage Publishing in February 2017, there are 27 original works of Nazmi Bosna composed for classical guitar. These works had been conducted from 2014 till the publication date of the book (Bosna, 2017a). The works and information about them are presented in Table 5 .

Table 5. Pieces in the $5^{\text {th }}$ Book

\begin{tabular}{|c|c|c|c|}
\hline Name of Work & Dedicated to & Tonality & Time Signature \\
\hline Etude No.23 & Soner Uluocak & B Minör & $2 / 4$ \\
\hline Etude No.24 & Soner Egesel & $*$ & $2 / 4$ \\
\hline Etude No.25 & Kaan Öztutgan & $*$ & $2 / 4-3 / 4$ \\
\hline Nocturne No.5 & Mutlu Torun & D Minor & $2 / 4-3 / 4$ \\
\hline Tango No.6 & - & D Minor & $4 / 4$ \\
\hline Piece No.22 & Dorukhan Ersin & $*$ & $3 / 4$ \\
\hline Piece No.23 & Soner Uluocak & D Major & $3 / 4-2 / 4$ \\
\hline Piece No.24 & Soner Egesel & $*$ & $3 / 4-2 / 4$ \\
\hline Piece No.25 & Ercüment Burak Erdoğan & $*$ & $2 / 4-3 / 4$ \\
\hline Piece No.26 & - & $*$ & $3 / 4-2 / 4$ \\
\hline Piece No.27 & Eren Süalp & B Minör & $2 / 4-3 / 4$ \\
\hline Piece No.28 & - & A Major & $2 / 4-3 / 4$ \\
\hline Piece No.29 & İsmail Sezen & A Major & $2 / 4-3 / 4-4 / 4$ \\
\hline Piece No.30 & Eren Süalp & $*$ & $2 / 4-3 / 4$ \\
\hline Piece No.31 & - & C Minor & $2 / 4-3 / 4$ \\
\hline Piece No.32 & Dorukhan Ersin & $*$ & $2 / 4-3 / 4-4 / 4$ \\
\hline Piece No.33 & Kağan Korad & $*$ & $2 / 4-3 / 4$ \\
\hline Piece No.34 & - & D Minor & $2 / 4$ \\
\hline Piece No.35 & Ahmet Kanneci & D Major & $5 / 8-7 / 8-6 / 8-3 / 8-2 / 4-10 / 8-8 / 8-9 / 8-3 / 4-11 / 8$ \\
\hline Piece No.36 & İsmail Sezen & D Minor & $4 / 4-3 / 4-2 / 4-7 / 8$ \\
\hline Piece No.37 & İsmail Sezen & $*$ & $3 / 4-2 / 4$ \\
\hline Piece No.38 & Ahmet Kanneci & $*$ & $3 / 4-2 / 4$ \\
\hline Piece No.39 & Sevgi-Engin Gümüştaş & E Minor & $2 / 4$ \\
\hline Piece No.40 & Hande Cangökçe & $*$ & $6 / 8$ \\
\hline Piece No.41 & Kürşad Terci & $*$ & $2 / 4-3 / 4-4 / 4$ \\
\hline Piece No.42 & - & C Major & $2 / 4-3 / 4-4 / 4$ \\
\hline Piece No.43 & Ahmet Kanneci & * & $4 / 4-3 / 4-2 / 4-5 / 8$ \\
\hline
\end{tabular}

Table 5 shows that the composer includes works in different types of western music in this book. Of these works, approximately $81 \%$ have the title Piece, $4 \%$ Tango, $4 \%$ Nocturne and $11 \%$ Etude. As in his 3 rd book, the composer preferred "Piece" title for most of the works in this book. So, it is not possible to make a definite judgment and classification about the type of works with the title of "Piece". Nevertheless, it is possible to say that the time signature has been changed in approximately $74 \%$ of the works in the book.

Regarding tonality, while approximately $15 \%$ of the works are in D Minor, $7 \%$ in B Minor, $7 \%$ in D Major, $7 \%$ in A Major, 4\% in C Minor, 4\% in E Minor, and 4\% C Major, 14\% of the works can not be considered within a single tonality or are terminated changing a tone different from the initial one. There are works dedicated to Soner Uluocak, Soner Egesel, Kaan Öztutgan, Mutlu Torun, Dorukhan Ersin, Ercüment Burak Erdoğan, Eren Süalp, İsmail Sezen, Kağan Korad, Ahmet Kanneci, İsmail Sezen, Sevgi-Engin Gümüştaş, Hande Cangökçe and Kürşad Terci in the book. 
23 pieces for classical guitar "Anatolian Breezes" (6. book). In this 73-page book published by Sage Publishing in February 2017, there are 23 original works of Nazmi Bosna composed for classical guitar. These works had been conducted from 2014 till the publication date of the book (Bosna, 2017b). The works and information about them are presented in Table 6.

Table 6. Pieces in the $6^{\text {th }}$ Book

\begin{tabular}{|c|c|c|c|}
\hline Name of Work & Dedicated to & Tonality & Time Signature \\
\hline Anatolian Breeze No.31 & Turgay Erdener & F Minor & $7 / 8-8 / 8-2 / 4-3 / 4-5 / 8$ \\
\hline Anatolian Breeze No.32 & Mutlu Torun & $*$ & $8 / 8-7 / 8-10 / 8-6 / 8-2 / 4-5 / 8-3 / 4-3 / 8-4 / 4$ \\
\hline Anatolian Breeze No.33 & Ahmet Kanneci & E Minor & $2 / 4-3 / 4-3 / 8-5 / 8$ \\
\hline Anatolian Breeze No.34 & Ahmet Kanneci & $*$ & $7 / 8-3 / 8-2 / 4-5 / 8-8 / 8-10 / 8-9 / 8-3 / 4$ \\
\hline Anatolian Breeze No.35 & Zülüf Öztutgan & $*$ & $7 / 8-3 / 8-6 / 8-3 / 4$ \\
\hline Anatolian Breeze No.36 & Ziya Aydıntan & A Minor & $7 / 8-8 / 8-5 / 8-3 / 4-3 / 8-2 / 4$ \\
\hline Anatolian Breeze No.37 & Kaan Öztutgan & $*$ & $3 / 4-7 / 8-5 / 8-2 / 4-3 / 8-9 / 8-8 / 8$ \\
\hline Anatolian Breeze No.38 & Ercüment Burak Erdoğan & $*$ & $3 / 4-8 / 8-7 / 8-2 / 4-5 / 8-4 / 4-11 / 8$ \\
\hline Anatolian Breeze No.39 & Soner Uluocak & A Minor & $4 / 4-3 / 8-2 / 4-8 / 8-6 / 8-10 / 8-7 / 8-5 / 8-3 / 4$ \\
\hline Anatolian Breeze No.40 & Soner Uluocak & $*$ & $7 / 8-2 / 4-5 / 8-3 / 4-3 / 8$ \\
\hline Anatolian Breeze No.41 & Zülüf Öztutgan & $*$ & $5 / 8-6 / 8-2 / 4-7 / 8-8 / 8-3 / 8-3 / 4$ \\
\hline Anatolian Breeze No.42 & İsmail Sezen & E Minor & $7 / 8-10 / 8-6 / 8-3 / 4-3 / 8-2 / 4-5 / 8-8 / 8$ \\
\hline Anatolian Breeze No.43 & Ercüment Burak Erdoğan & E Minor & $3 / 8-2 / 4-4 / 4-9 / 8-8 / 8-5 / 8-3 / 4-7 / 8$ \\
\hline Anatolian Breeze No.44 & Dorukhan Ersin & $*$ & $3 / 8-2 / 4-3 / 4-8 / 8-5 / 8-6 / 8-7 / 8$ \\
\hline Anatolian Breeze No.45 & Eren Süalp & $*$ & $4 / 4-2 / 4-5 / 8-8 / 8-3 / 4-7 / 8-3 / 8$ \\
\hline Anatolian Breeze No.46 & Soner Egesel & $*$ & $4 / 4-11 / 8-7 / 8-10 / 8-2 / 4-6 / 8-3 / 4-5 / 8-3 / 8$ \\
\hline Anatolian Breeze No.47 & Soner Egesel & D Minor & $4 / 4-3 / 4-5 / 8-2 / 4-7 / 8-6 / 8-3 / 8$ \\
\hline Anatolian Breeze No.48 & Hande Cangökçe & E Minor & $2 / 4-3 / 8-3 / 4-5 / 8-4 / 4-7 / 8-6 / 8$ \\
\hline Anatolian Breeze No.49 & Eren Süalp & $*$ & $9 / 8-7 / 8-8 / 8-4 / 4-3 / 4-2 / 4-5 / 8-6 / 8-3 / 8$ \\
\hline Anatolian Breeze No.50 & Kaan Öztutgan & $*$ & $4 / 4-2 / 4-5 / 8-9 / 8-7 / 8-6 / 8-3 / 4-3 / 8$ \\
\hline Anatolian Breeze No.51 & Dorukhan Ersin & D Minor & $5 / 8-2 / 4-7 / 8-3 / 4-4 / 4-9 / 8-3 / 8-6 / 8$ \\
\hline Anatolian Breeze No.52 & Soner Egesel & $*$ & $3 / 4-2 / 4-5 / 8-7 / 8-4 / 4-6 / 8-3 / 8$ \\
\hline Anatolian Breeze No.53 & Savaş Çekirge & $*$ & $4 / 4-9 / 8-8 / 8-3 / 8-7 / 8-5 / 8-10 / 8-6 / 8-2 / 4$ \\
\hline
\end{tabular}

When Table 6 is examined, it is seen that the composer preferred a general name "Anatolian Breeze" for the works in this book. For this reason, it is not possible to make a definite judgment about the type of works and to make a classification. However, it is possible to say that the time signature has been changed in all the works in the book.

As for tonality, about $17 \%$ of the works have E Minor, 9\% A Minor, 9\% D Minor, 4\% F Minor while $61 \%$ of the works cannot be evaluated within a single tonality or are ended in a different tone from the initial tone. It was terminated by switching to tone. The book includes works dedicated to Turgay Erdener, Mutlu Torun, Ahmet Kanneci, Zülüf Öztutgan, Ziya Aydıntan, Kaan Öztutgan, Ercüment Burak Erdoğan, Soner Uluocak, İsmail Sezen, Dorukhan Ersin, Eren Süalp, Soner Egesel, Hande Cangökçe and Savaş Çekirge.

34 pieces for classical guitar (7. book). In this 166-page book published by Sage Publishing in February 2017, there are 34 original works of Nazmi Bosna composed for classical guitar. These works had been conducted from 2017 till the publication date of the book (Bosna, 2018a). The works and information about them are given in Table 7.

Table 7. Pieces in the $7^{\text {th }}$ Book

\begin{tabular}{|l|l|l|l|}
\hline Name of Work & Dedicated to & Tonality & Time Signature \\
\hline Etude No.26 & Kürşad Terci & $*$ & $3 / 4-2 / 4$ \\
\hline Etude No.27 & Kağan Korad & E Minor & $2 / 4-3 / 4$ \\
\hline Etude No.28 & Zülüf Öztutgan & $*$ & $2 / 4$ \\
\hline Piece No.44 & İsmail Sezen & $*$ & $3 / 4-2 / 4$ \\
\hline Piece No.45 & Bekir Küçükay & D Major & $2 / 4-3 / 4-4 / 4$ \\
\hline Piece No.46 & M.Safa Yeprem & $*$ & $3 / 4-2 / 4$ \\
\hline Piece No.47 & Gülay Bosna & $*$ & $2 / 4-3 / 4$ \\
\hline Piece No.48 & Kürşad Terci & C Minor & $3 / 4-2 / 4$ \\
\hline Piece No.49 & Dorukhan Ersin & $*$ & $2 / 4-3 / 4$ \\
\hline Piece No.50 & Kağan Korad & G Minor & $2 / 4-3 / 4$ \\
\hline
\end{tabular}




\begin{tabular}{|l|l|l|l|}
\hline Piece No.51 & Kağan Korad & $*$ & $3 / 4-2 / 4$ \\
\hline Piece No.52 & Soner Egesel & E Major & $3 / 4-2 / 4$ \\
\hline Piece No.53 & Kürşad Terci & $*$ & $2 / 4-3 / 4$ \\
\hline Piece No.54 & Aziz Bosna & $*$ & $2 / 4-3 / 4$ \\
\hline Piece No.55 & & $*$ & $3 / 8$ \\
\hline Piece No.56 & Ahmet Kanneci & E Major & $3 / 4-2 / 4$ \\
\hline Piece No.57 & Mutlu Torun & A Minor & $3 / 4-2 / 4$ \\
\hline Piece No.58 & & $*$ & $2 / 4-3 / 4$ \\
\hline Piece No.59 & Soner Egesel & A Minor & $2 / 4-3 / 4$ \\
\hline Piece No.60 & Kaan Öztutgan & A Minor & $2 / 4-3 / 4$ \\
\hline Piece No.61 & & A Minor & $2 / 4$ \\
\hline Piece No.62 & Soner Uluocak & $*$ & $3 / 8$ \\
\hline Piece No.63 & & E Minor & $3 / 4-2 / 4$ \\
\hline Piece No.64 & Melih Güzel & E Minor & $3 / 8$ \\
\hline Piece No.65 & Ercüment Burak Erdoğan & E Minor & $2 / 4$ \\
\hline Piece No.66 & Hande Cangökçe & $*$ & $3 / 4-2 / 4$ \\
\hline Piece No.67 & Kağan Korad & $*$ & $3 / 4-2 / 4$ \\
\hline Piece No.68 & Hande Cangökçe & $*$ & $2 / 4-3 / 4-6 / 8-5 / 8-8 / 8$ \\
\hline Piece No.69 & Eren Süalp & $*$ & $2 / 4-3 / 4$ \\
\hline Piece No.70 & Kürşad Terci & E Minor & $3 / 4-2 / 4-5 / 8$ \\
\hline Piece No.71 & Kürşad Terci & D Flat Major & $2 / 4-2 / 4-4 / 4$ \\
\hline Piece No.72 & Kağan Korad & $*$ & $2 / 4-3 / 4$ \\
\hline Piece No.73 & Soner Çiftçioğlu & \\
\hline Piece No.74 & & \\
\hline
\end{tabular}

Table 7 reveals that the composer includes works in different types of western music in this book. Approximately $91 \%$ of these works have the title "Piece" and $9 \%$ have the title "Etude". It is seen that the composer preferred a general name, "Piece" in most of the works in this book. That's why, it is not possible to make a definite judgment and classification about the type of works with the title of "Piece". However, it is possible to say that the time signature has been changed in about $82 \%$ of the works in the book.

The tonality evaluation displays that while approximately $15 \%$ of the works are in E Minor, $12 \%$ in A Minor, $6 \%$ in E Major, 3\% in D Major, 3\% in C Minor, 3\% in G Minor, and 3\% D flat Major, 55\% of the works can not be evaluated within a single tonality or are terminated changing to a tone different from the initial one. There are works dedicated to Kürşad Terci, Kağan Korad, Zülüf Öztutgan, İsmail Sezen, Bekir Küçükay, M.Safa Yeprem, Gülay Bosna, Dorukhan Ersin, Soner Egesel, Aziz Bosna, Ahmet Kanneci, Mutlu Torun, Kaan Öztutgan, Soner Uluocak, Melih Güzel, Ercüment Burak Erdoğan, Hande Cangökçe, Eren Süalp and Soner Çiftçioğlu in the book.

19 pieces for classical guitar 'Anatolian Breezes' (8. book). In this 66-page book published by Sage Publishing in March 2018, there are 34 original works of Nazmi Bosna composed for classical guitar. These works had been conducted from 2017 till the publication date of the book (Bosna, 2018b). The works and information about them are given in Table 8 .

Table 8. Pieces in the $8^{\text {th }}$ Book

\begin{tabular}{|l|l|l|l|}
\hline Name of Work & Dedicated to & Tonality & Time Signature \\
\hline Anatolian Breeze No.54 & Zülüf Öztutgan & $*$ & $7 / 8-8 / 8-9 / 8-3 / 4-2 / 4-5 / 8-4 / 4-10 / 8-3 / 8-6 / 8$ \\
\hline Anatolian Breeze No.55 & Kaan Öztutgan & $*$ & $7 / 8-8 / 8-4 / 4-5 / 8-2 / 4-3 / 8$ \\
\hline Anatolian Breeze No.56 & Melih Güzel & $*$ & $5 / 8-4 / 4-2 / 4-3 / 4-7 / 8-9 / 8-3 / 8$ \\
\hline Anatolian Breeze No.57 & Mutlu Torun & $*$ & $5 / 8-8 / 8-7 / 8-2 / 4-3 / 8-3 / 4$ \\
\hline Anatolian Breeze No.58 & Kağan Korad & E Minor & $8 / 8-10 / 8-5 / 8-7 / 8-6 / 8-2 / 4-3 / 4-4 / 4-9 / 8$ \\
\hline Anatolian Breeze No.59 & Kürşad Terci & $*$ & $7 / 8-10 / 8-6 / 8-5 / 8-3 / 8-3 / 4-4 / 4-2 / 4-8 / 8$ \\
\hline Anatolian Breeze No.60 & Kağan Korad & $*$ & $7 / 8-10 / 8-3 / 8-6 / 8-9 / 8-2 / 4-3 / 4-5 / 8$ \\
\hline Anatolian Breeze No.61 & Soner Egesel & E Minor & $3 / 8-2 / 4-7 / 8-5 / 8-10 / 8-9 / 8-3 / 4-6 / 8$ \\
\hline Anatolian Breeze No.62 & Eren Süalp & $9 / 8-8 / 8-3 / 4-2 / 4-7 / 8-5 / 8$ \\
\hline Anatolian Breeze No.63 & M.Betigül Ayhan & & $3 / 8-2 / 4-5 / 8-7 / 8-6 / 8-10 / 8$ \\
\hline Anatolian Breeze No.64 & Çobancioğlu and & \\
\hline Anatolian Breeze No.65 & Çobancioğlu & G Minor & $7 / 8-10 / 8-5 / 8-3 / 8-2 / 4-3 / 4$ \\
\hline Anatolian Breeze No.66 & Ercüment Burak Erdoğan & A Minor & $7 / 8-6 / 8-3 / 4-5 / 8-2 / 4-8 / 8-9 / 8-10 / 8$ \\
\hline Anatolian Breeze No.67 & Kürşad Terci & $*$ & $10 / 8-9 / 8-5 / 8-8 / 8-7 / 8-4 / 4-3 / 4-3 / 8$ \\
\hline Anatolian Breeze No.68 & Ahmet Kanneci & $5 / 8-2 / 4-7 / 8-10 / 8-3 / 4-8 / 8-3 / 8$ \\
\hline
\end{tabular}




\begin{tabular}{|l|l|l|l|}
\hline Anatolian Breeze No.69 & Bekir Küçükay & E Minor & $3 / 4-7 / 8-4 / 4-5 / 8-2 / 4-6 / 8-8 / 8-12 / 8-11 / 8-9 / 8-3 / 8-10 / 8$ \\
\hline Anatolian Breeze No.70 & Kağan Korad & E Minor & $2 / 4-8 / 8-3 / 8-4 / 4-6 / 8-5 / 8-7 / 8-3 / 4-10 / 8$ \\
\hline Anatolian Breeze No.71 & Mutlu Torun & E Minor & $10 / 8-7 / 8-5 / 8-3 / 8-2 / 4-8 / 8-3 / 4$ \\
\hline Anatolian Breeze No.72 & Kürşad Terci & D Minor & $3 / 4-2 / 4-6 / 8-4 / 4-7 / 8-8 / 8-3 / 8-5 / 8-9 / 8$ \\
\hline
\end{tabular}

Table 8 shows that the composer preferred a general name "Anatolian Breezes" for the works in this book. For this reason, it is not possible to make a definite judgment about the type of works and to make a classification. On the other hand, it is possible to say that the time signature has been changed in all the works in the book.

Concerning tonality, approximately $32 \%$ of the works have E Minor, 5\% G Minor, 5\% A Minor, 5\% D Minor while $53 \%$ of the works cannot be evaluated within a single tonality or are ended in a different tone from the initial tone. The book includes works dedicated to Zülüf Öztutgan, Kaan Öztutgan, Melih Güzel, Mutlu Torun, Kağan Korad, Kürşad Terci, Soner Egesel, Eren Süalp, Ercüment Burak Erdoğan, Ahmet Kanneci, Hande Cangökçe, Bekir Küçükay, M.Betigül Yürüten Çobancıoğlu and Ayhan Çobancıŏglu.

Guitar applied harmony teaching (9. book). In this 389-page book published by Sage Publishing in March 2019, guitar applied harmony teaching is included in this book. This book, which is a compilation of the works in the bibliography of the book, was prepared by taking the opinions of the instructors working in the guitar departments of the conservatories. (Bosna, 2019). Information about the chapters and subjects in the book is presented in Table 9.

Table 9. Chapters in the $9^{\text {th }}$ Book

\begin{tabular}{|l|l|}
\hline Chapters & Subject \\
\hline 1. Chapter & Basic Music Knowledge \\
\hline 2. Chapter & Interval \\
\hline 3. Chapter & Cadences, Chords, and Chord Links \\
\hline 4. Chapter & Foreign Sounds to Harmony \\
\hline 5. Chapter & Alteration and Enharmonic \\
\hline 6. Chapter & Modulation \\
\hline
\end{tabular}

As seen in Table 9, this book consists of 6 chapters: "Basic Music Knowledge", "Interval", "Cadences, Chords and Chord Connections", " Foreign Sounds to Harmony", "Alteration and Enharmonic", and "Modulation". From a closer examination, it is clear that each chapter is handled in a very comprehensive way and aims to teach the traditional harmony approach on the guitar starting from the most basic subjects.

\section{General Features of His Works}

The most prominent feature in Nazmi Bosna's compositions is that the near or far tones are often modulated, and the time signature changes persistently. Similarly, it is seen that most of his works do not end by turning to the axis of the starting tone, as in the traditional harmony approach, but end in the axis of a different tone or in the dominant degree. In this sense, it is possible to say that most of the works have a structure that is far from certain basic patterns. However, although the works are directed to different tonal structures, there is a certain concept of tonality in all the works of the composer. Almost all of the composer's works are in Lied form. Although he is a composer with a guitarist origin, Bosna does not include guitar techniques such as glissando and harmonic in his works, and preferred to use the polyphonic structure of the guitar in a rich way.

It is possible to examine the composer's works under two main headings. While one of them consists of works of classical western music, the other consists of works that mostly aim to reflect Turkish culture. Works of western music types are included in the books, which have works with different characters such as Milonga, Tango, 
Nocturne, Serenade, Vals, Prelude, and Etude. The composer has named most of his works for classical music as Piece since his 4th book. Among these works, it is observed that elements such as rhythmic structure and time signature are meticulously followed in works with certain characteristic features such as Waltz, Tango, Milonga, but in works of free form such as Etude and Prelude, time signature is frequently changed, and the sounds that are foreign to the chord and tonality are freely used.

Also, Nazmi Bosna named the works that aimed to reflect Turkish culture as "Anatolian Breezes". It is seen that in these works there are melodies similar to the features of the maqam used in Turkish music, and there are also rhythms often used in Turkish music such as $9 / 8,7 / 8$ and $5 / 8$.

\section{The Contributions of Nazmi Bosna to Classical Guitar Education}

Nazmi Bosna is one of the first Turkish guitarists to study classical guitar abroad. In this respect, Bosna pioneered many guitarists who wanted to study classical guitar abroad in the 70's. After coming back to Turkey, Bosna, who worked with the world-renowned guitar virtuoso and instructor Miguel Rubio in such an important institution like Bern Conservatory, shared his knowledge and experience with the guitarists in our country. Likewise, with the guitar lessons he has given, Bosna has contributed to the training of many guitarists, including Ahmet Kanneci.

He has contributed to the development and enrichment of the classical guitar repertoire with the compositions he has made since 1963. Furthermore, the works of Bosna were included in the curriculum of various educational institutions. Aiming to increase their motivation, Bosna dedicated these works to many guitar instructors and guitarists. The notes of his works are shared free of charge on his personal website (www.nazmibosna.com) and made available to guitarists who have no financial means.

With the Guitar Applied Harmony book published in 2019, Bosna has provided a comprehensive resource to assist guitarists in harmony training. By this means, it has enabled guitarists who do not have piano lessons in their curriculum to apply and learn harmony rules on the guitar.

\section{Conclusion}

\section{Results Regarding the Life of Nazmi Bosna}

The results indicated that Nazmi Bosna began his guitar education by taking classical guitar lessons from Ziya Aydintan, and he continued his academic classical guitar education as a student of Miguel Rubio at the Bern Conservatory in Switzerland. Also, he made his first composition in 1963 and has continued to compose since then. It was also found that he published his compositions in a book in 2011, and since then, he has focused more on his composition studies. He gave classical guitar lessons at some music schools in Bern as long as he studied in Switzerland, and some of his works got attention and performed abroad. In addition, he gave private guitar lessons in Ankara.

\section{Results Regarding the Works of Nazmi Bosna}

1- Bosna has 9 published books: 42 Pieces for Classical Guitar ( $1^{\text {st }}$ book), 20 Pieces for Classical Guitar ( $2^{\text {nd }}$ Book), 30 Pieces for Classical guitar “Anatolian Breezes” ( $3^{\text {rd }}$ book), 25 Pieces for Classical Guitar ( $4^{\text {th }}$ Book), 27 Pieces for Classical Guitar ( $5^{\text {th }}$ Book), 23 Pieces for Classical Guitar “Anatolian Breezes" (6 $6^{\text {th }}$ Book), 34 Pieces for Classical Guitar ( $7^{\text {th }}$ Book), 19 Pieces for Classical Guitar “Anatolian Breezes” ( $8^{\text {th }}$ Book), and Guitar Applied 
Harmony Teaching ( $9^{\text {th }}$ Book). The number of his works in these books is 230 . Thus, it can be concluded that Nazmi Bosna is the composer who has the most original works for solo classical guitar in our country.

2- It is found that Bosna's works have been collected into books with two different understandings: one reflecting Turkish culture, “Anatolian Breezes”, and one including different types of Classical Western Music. Of these books, 1., 2., 4., 5. and 7th ones include different types of Classical Western Music, 3., 6. and the 8th books include works reflecting Turkish culture. Of these works, 74 have Piece, 72 Anatolian Breezes, 28 Etude, 10 Walzer, 6 Tango, 6 Milonga, 5 Nocturne, 3 Prelude, 3 Serenade, 2 Romanze, 2 Tanz, 1 Tanz Der Inka, 1 Elegie, 1 Grand Solo, 1 Menuett, 1 Barcelona-Erinnerungen, 1 Ein Abend In Madrid, 1 Traum, 1 Andante Religioso and 1 Spanische Caprichio titles.

3- As for tonality, it is seen that the composer has tones in A Major, A Minor, B Minor, C Major, C Minor, D Major, D Minor, D Flat Major, E Major, E Minor, F Minor, G Major, and G Minor. Also, he has works that cannot be evaluated in a single tonality. About $35 \%$ of the composer's works have a structure that cannot be considered within a single tonality. $19 \%$ of the composer's works are in E minor, $15 \%$ in A minor and 12\% in D Minor, and these tones are the most used tonalities in his works.

4- The most prominent feature in Nazmi Bosna's compositions is that the near or far tones are often modulated, and the time signature changes persistently. Likewise, it is seen that most of his works do not end by turning to the axis of the starting tone, as in the traditional harmony approach, but end in the axis of a different tone or in the dominant degree. In this way, it can be concluded that most of the works have a structure that is far from certain basic patterns. Nevertheless, although the composer tends towards different tonal structures in his works, there is a certain concept of tonality in all the works of the composer. Almost all of the composer's works are in Lied form.

5- Although he is a composer of guitarist origin, Bosna, who does not include guitar techniques such as glissando and harmonic in his works, prefers to use the polyphonic structure of the guitar in a rich way.

6- Bosna's Guitar Applied Harmony Teaching book consists of 6 chapters: "Basic Music Knowledge", "Interval", "Cadences, Chords and Chord Connections", "Foreign Sounds to Harmony", "Alteration and Enharmonic", and "Modulation". The closer examination of the book reveals that each chapter is handled in a very comprehensive way, and also this book is capable of teaching traditional harmony rules on the guitar in a practical way.

\section{Contributions of Nazmi Bosna to Guitar Education}

1- After coming back to Turkey, Bosna, who worked with the world-renowned guitar virtuoso and instructor Miguel Rubio in such an important institution like Bern Conservatory, shared his knowledge and experience with the guitarists in our country. Likewise, with the guitar lessons he has given, Bosna has contributed to the training of many guitarists, including Ahmet Kanneci.

2- He has contributed to the development and enrichment of the classical guitar repertoire with the compositions he has made since 1963. Similarly, the works of Bosna were included in the curriculum of various educational institutions. Aiming to increase their motivation, Bosna dedicated these works to many guitar instructors and guitarists. The notes of his works are shared free of charge on his personal website, and so he has made them available to guitarists who have no financial means. 
3- With the Guitar Applied Harmony book published in 2019, Bosna has provided a comprehensive resource to assist guitarists in harmony training. Thus, it has enabled guitarists who do not have piano lessons in their curriculum to apply and learn harmony rules on the guitar.

\section{Suggestions}

1- The composer's works can be analyzed comprehensively in terms of harmony and form.

2- Classification of the works according to their technical difficulty can help the people who will work with these works, and the instructors who will use them as training materials.

3- Guitar Applied Harmony book can be used as a reference book, especially in the guitar art branches of the institutions providing professional music education.

4- The recognition and vocalization of the composer's works by the guitarists can be investigated.

\section{References/Kaynakça}

Bosna, N. (2011a). 42 Works For Classical Guitar. Istanbul: Bemol Music Publishing. Bosna, N. (2011b). 20 Works For Classical Guitar. Istanbul: Bemol Music Publishing.

Bosna, N. (2014a). 30 Pieces For Classical Guitar “Anatolian Breezes”. Ankara: Sage Publishing. Bosna, N. (2014b). 25 Pieces For Classical Guitar. Ankara: Sage Publishing. Bosna, N. (2017a). 27 Pieces For Classical Guitar. Ankara: Sage Publishing. Bosna, N. (2017b). 23 Pieces For Classical Guitar “Anatolian Breezes”. Ankara: Sage Publishing. Bosna, N. (2018a). 34 Pieces For Classical Guitar. Ankara: Sage Publishing.

Bosna, N. (2018b). 19 Pieces For Classical Guitar “Anatolian Breezes”. Ankara: Sage Publishing. Bosna, N. (2019). Guitar Applied Harmony Teaching. Ankara: Sage Publishing.

Bosna,N. (2021, February 12). Access address: http://www.nazmibosna.com

Elmas, Y. (2003). Guitar With Questions. Istanbul: Pan Publishing.

Jeffery, B. (2002), The music: composers, in, The classical guitar book a complete history (p.108-111) San Francisco: Backbeat Books.

Ranjbari, M. (2013). Framing Models To Demonstrate Classical Guitar's Technical Attributions \& Idiomatic Figures To Non-Guitarist Composers. (Unpublished Master's Thesis), Hacettepe University Institute Of Fine Art, Ankara.

Ünlenen, E. (2016). The Composers Who Gave A Direction To The Modern Guitar Music Between 1920 And 1950. Journal Of Art And Design, 6 (2), 110-126. DOI: 10.20488/www-std-anadolu-edu-tr.292709

Yeprem, S. (2013, July 25). Guitar Music Studies in Turkey. Retrieved on February 28, 2021 from the http://www.safayeprem.com/turkiyede-gitar-muzigi-calismalari/ 